\title{
Community-based wastewater farming and its contribution to livelihoods of the urban poor: Case of Nairobi, Kenya
}

\author{
Mary Njenga ${ }^{1,4} *$, Nancy Karanja ${ }^{1}$, Gordon Prain ${ }^{2}$, Kuria Gathuru $^{3}$, and Diana Lee-Smith ${ }^{5}$
}

Submitted 28 June 2010 / Accepted 6 January 2011 / Published online 30 April 2011

Citation: Njenga, M., Karanja, N., Prain, G., Gathuru, K., \& Lee-Smith, D. (2011). Community-based wastewater farming and its contribution to livelihoods of the urban poor: Case of Nairobi, Kenya. Journal of Agriculture, Food Systems, and Community Development, 1(3), 151-162. http://dx.doi.org/10.5304/jafscd.2011.013.004

Copyright (C) 2011 by New Leaf Associates, Inc.

\begin{abstract}
No current and reliable estimates of the number of people participating in urban agriculture exist; however, Smit and Nasr roughly estimated the number to be about 800 million (Smit, Ratta, \& Nasr, 1996). Other estimates predict that in 2020, 35 to 40 million urban residents of Africa will depend on urban agriculture to feed themselves (Denninger, Egero, \& Lee-Smith, 1998). In 2008 the world's urban population outnumbered its rural population for the first time. It is estimated that the world's

\footnotetext{
${ }^{1}$ University of Nairobi, P.O. Box 30197-00100, Nairobi, Kenya; m.njenga@cgiar.org; nancy.karanja@cgiar.org

2 Urban Harvest-International Potato Centre, Lima Office, Av. La Molina 1895, Apartado 1558, La Molina, Lima Peru; g.prain@,cgiar.org

${ }^{3}$ Kenya Green Towns Partnership Association, P.O. Box 69420-00400, Nairobi, Kenya; greentowns2002@yahoo.com

${ }^{4}$ World Agroforestry Centre, P.O. Box 30677-00100, Nairobi Kenya.

${ }^{5}$ Mazingira Institute, P.O. Box 14550, Nairobi 00800 Kenya; diana.leesmith@gmail.com

* Corresponding author
}

urban population will double from 3.3 billion in 2007 to 6.4 billion in 2050 , and that by $2030,6 \%$ of the world's population will live in cities (UNFPA, 2007). In most developing countries, more than half of the urban population lives below the poverty level of USD1 per day (UN, 2008). To cope with urban poverty, many people turn to farming; it is estimated that between $15 \%$ and $20 \%$ of food throughout the world is produced in urban and peri-urban areas (Armar-Klemesu, 2000).

Estimates show that at least two million hectares (4.9 million acres) in both urban and rural areas around the world are irrigated with treated, untreated, or partially treated wastewater (Jimenez \& Asano, 2004). We carried out a study in Nairobi aimed at generating data on the contributions of wastewater farming to the livelihoods of the urban poor. The survey among 232 wastewater-farming households was complemented by focus-group discussions in two informal settlements in Nairobi, and revealed that wastewater farming benefited both farmers and their neighbors by providing food, employment, and income. Over $60 \%$ of labor was provided by women. Fewer than half the 
farmers used manure or chemical fertilizer, as many believed that wastewater contains plant-based nutrients. The wastewater farmers experienced challenges in insecure land tenure, conflict with the city council, conflict in sharing resources, and competition for space between farming and housing. There was a generally low level of knowledge about the safe use of pesticides among those surveyed, and further research is recommended on this topic as well as on the health risks of wastewater farming. There also is a need to establish platforms to discuss and resolve resource-use conflicts in wastewater farming, as well as on issues related to incorporating urban agriculture into urban land use.

\section{Keywords}

Wastewater farming, urban agriculture, informal settlements, Kenya

\section{Background and Research Objectives}

Though the crisis in world food prices exploded during 2008, food insecurity in Africa has been a fact of life for many low-income urban dwellers for decades, and especially since the period of structural adjustments in the 1980s (Maxwell, 1995). The problem is not a lack of food; it's that poor urban consumers cannot afford it. This is the stark but simple truth lying behind much of the inequitable distribution of wealth across many African cities. What urban households have known and practiced for generations, urban decisionmakers have begun to recognize more recently: urban agriculture is an important livelihood strategy (Prain, Karanja, \& Lee-Smith, 2010). Although rural agriculture has a major role to play in meeting urban food needs, urban agriculture (UA) has great potential to help fill the gap during the food shortages that are common in Africa and that especially affect poor urban populations (Haluna, 2002). Some of the advantages urban agriculture has over rural agriculture include proximity to the major demand centers, low transportation cost between the farm gate and retail market, and reduction in postharvest losses due to reduced time between harvest and sales (Gyiele, 2002).
No current and reliable estimates of the number of people participating in UA exist; however, Smit and Nasr roughly estimated the number to be about 800 million (Smit, Ratta, \& Nasr, 1996). Of these, 200 million are considered to be market producers, employing 150 million people. Other estimates by Denninger, Egero, and Lee-Smith (1998) suggest that by 2020,35 million to 40 million urban residents in Africa will depend on UA to feed themselves.

Studies in nine African cities reveal that on average, $35 \%$ of households engage in some form of agriculture, but this rises to over $70 \%$ depending on their location along the peri-urban to urban transect (Foeken \& Mwangi, 2000; Nabulo, Oryem-Origa, \& Diamond, 2006; Prain, et al., 2010). Conservative estimates reported by ArmarKlemesu (2000) suggest that between 15\% and $20 \%$ of the world's food is produced in urban and peri-urban areas. Poverty is a big challenge in developing countries, and in Kenya, for instance, $56 \%$ of the population lives below USD1 per day (MoPND, 2003). Nairobi has the highest concentration of unemployment in the country, standing at 243,272 persons ( $9 \%$ ). Women make up $54 \%$ of this unemployed population (referred to as those seeking work or having no work available as reported under the population census) (GOK, 2010). Urban agriculture provides benefits to the economy in terms of employment and income, particularly for women and other disadvantaged groups among the poor.

The most important reasons why farmers in developing countries use wastewater for farming is its availability throughout the year as the only source of irrigation water, and the presence of plant nutrients in wastewater, which saves farmers the need of spending money for fertilizer. Wastewater in this paper refers to the liquid part of waste from households (black and greywater), farms, and industrial establishments, which may be mixed with groundwater, surface water, and stormwater (Metcalf \& Eddy, 2003). Millions of farmers globally use wastewater for agricultural production. Though the actual extent is not known, some estimates show that at least two 
million hectares (4.9 million acres) in both urban and rural areas are irrigated with treated, untreated, or partially treated wastewater (Jimenez \& Asano, 2004). In recent years wastewater has gained importance in water-scarce regions like the Middle East and North Africa. Projections show that the world population living in countries facing water scarcity will increase to about $40 \%$ by 2050 (Hinrichsen, Robey, \& Upadhyay, 1998). The expansion of urban populations translates into more fresh water being diverted to cities for domestic use. About $70 \%$ of this water returns as wastewater to the environment and could be recycled for farming (Faruqui, Niang, \& Redwood, 2004). Urban farmers make use of the nutrients in wastewater to enhance yields and ensure yearround food production. About 2,200 hectares $(5,436$ acres) are irrigated with water of varying quality within a $20 \mathrm{~km}$ (12.4 mile) radius of Nairobi (Hide, Kimani, \& Thuo, 2001). These urban and peri-urban farmers use water from streams (upstream) and indirectly or directly reuse untreated urban wastewater.

Irrigation with untreated wastewater, however, can present a major threat to public health (of both humans and livestock), food safety, and environmental quality (Scott, Faruqui, \& Rashid-Sally, 2004) since it contains disease-causing microorganisms. This may affect at least $10 \%$ of the world population that has been estimated to consume wastewater-irrigated produce (Smit \& Nasr, 1992). Further, untreated wastewater contains industrial effluents that carry toxic organic and inorganic chemicals, some of which can be bioaccumulated in plant tissues (Carr, Blumenthal, \& Mara, 2004).

Wastewater farming provides employment opportunities and is a way for urbanites to meet their food requirements and generate income. The potential contribution of wastewater farming to urban food systems is high, but it is not supported by an urban land-use policy framework in many countries, including Kenya. Thus not much attention is given to the activity. The aim of this study was to gain an understanding of the contribution of wastewater farming to the livelihoods of the urban poor, and of challenges that threaten this form of farming in two informal settlements in Nairobi, Kenya.

\section{Methods and Approaches}

Study Sites

The first study site included in this report is Maili Saba farm in Embakasi division of Nairobi, Maili Saba sublocation, with a population of about 10,000 (see figures 1a and 1b). Sixty-eight percent of the population in the sublocation practiced irrigated urban farming using untreated wastewater tapped from the main sewer line as it flows to the Ruai water treatment plant. The total area of this farm was 61 hectares (151 acres), and the land belonged to one of the residents who allowed farmers to use it on a temporary basis. The farmers are organized into the 1,500-member Siranga, Mwangenya, Ruaka Self-Help Group, most of whom have been farming at Maili Saba since the early 1980s. This group is a legal entity that was registered in 2003 with the Ministry of Gender, Children and Social Development and is managed by an executive committee. The group's activities are guided by a set of objectives that are to conserve and protect biodiversity and the environment along the Nairobi river basin, to generate income and employment through livelihood diversification, and to network urban farmers to enhance their bargaining power.

The second site included in this study was Kibera farm, located $10 \mathrm{~km}$ (6.2 miles) southwest of Nairobi and bordering Lang'ata Barracks and Uhuru Gardens on the southern side and the Kibera slum on the northern side (see figure 1b). Most of the farmers came from the Kibera slum, which has a population of about 750,000 and occupies an area of 4 square $\mathrm{km}$ (1.5 square miles), making it the largest and one of the most densely populated slums in Africa. The slum is characterized by poor water and sanitation conditions, high food insecurity, health problems (especially high child mortality), unemployment, and insecurity (UN-Habitat, 2006). The farm covered an area of eight hectares (20 acres) belonging to the National Social Security Fund (NSSF), which has 
Figure 1a. Map of Nairobi in the Context of Kenya

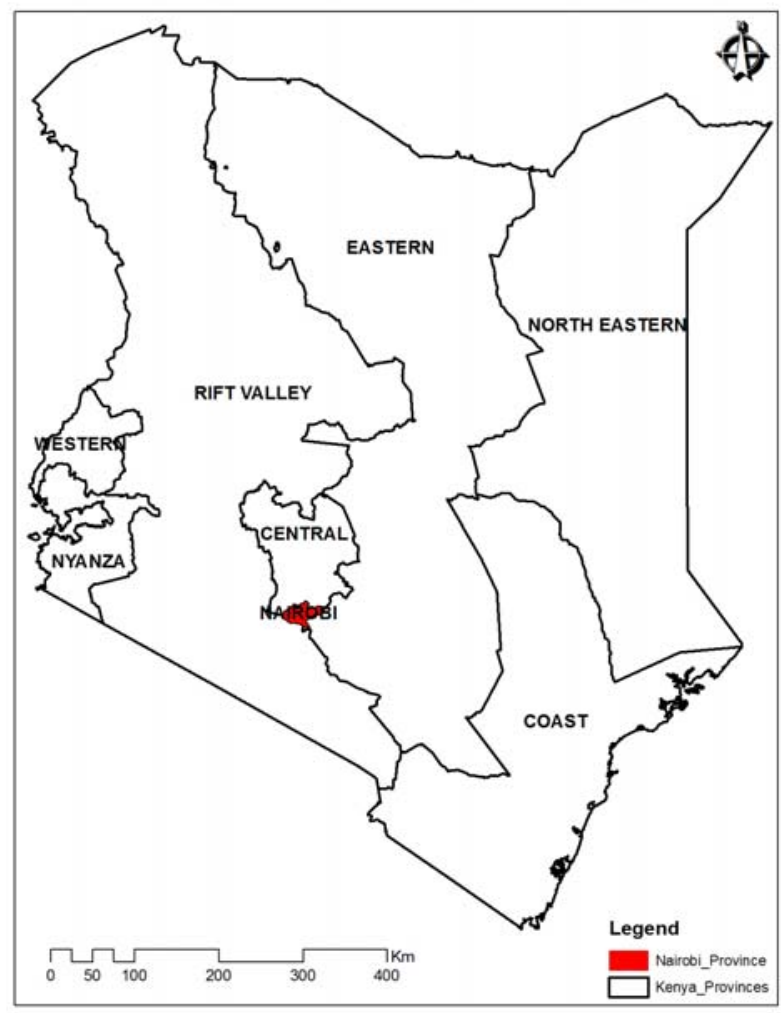

Map by Dennis Mwaniki.

Figure 1b. Map of Nairobi Showing Study Sites

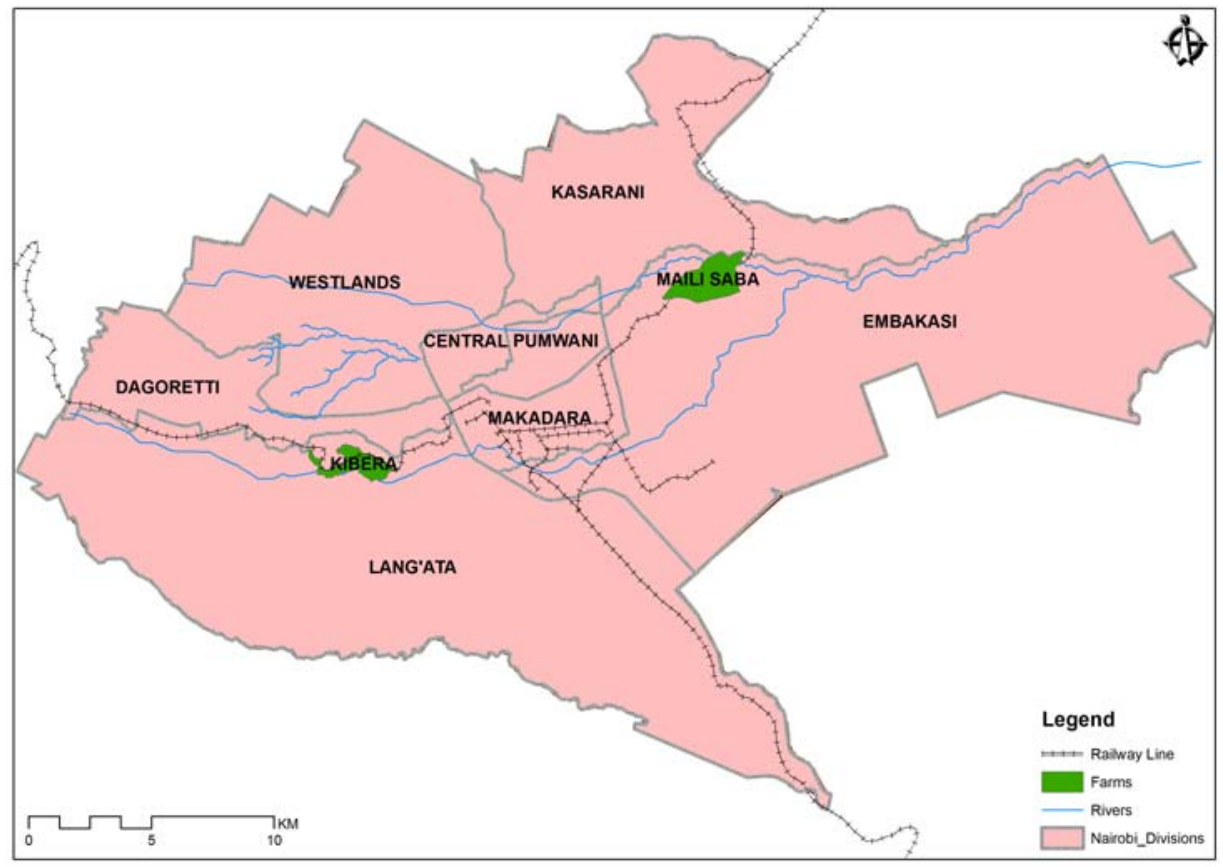

Map by Dennis Mwaniki. allowed the farmers to use the land for crop production under informal arrangements. The farmers have cultivated this land for the last 20 years using untreated wastewater.

These farmers, like their counterparts in Maili Saba, belong to an association. Theirs is known as Lang'ata Self Help Group and comprised 36 members (25 men and 11 women) at the time of the study. Lang'ata Self Help Group, as in the case at Maili Saba, is a legal entity registered with the same ministry. The farmers formed this legal entity in order to address their household food and nutrition needs, generate income, be self-employed, and address other challenges posed by the slum. The group is led by an executive committee and guided by a constitution that lays out rules and regulations.

\section{Socioeconomic Survey}

Surveys were conducted at 206 households in Maili Saba, a large farm with many farmer households, and at 26 households in Kibera, a small farm with few farmer households. At Maili Saba households were randomly selected from the three villages in the site: 71 households from Maili Saba, 10 from

Mwengenye, and 125 from Siranga. A representative sample in each of the three villages was determined based on the total population of wastewater farmers. After determining the sample size for each site, random selection of the respondents was done along footpaths, where every fifth household involved in wastewater farming was interviewed. At Kibera, all the households that were actively involved in wastewater farming formed the sample and those that were available 
during the time of the survey were interviewed.

A gender-sensitive and completely structured questionnaire was pretested, revised, and then administered to individual households to gather quantitative data on types of crops grown, land sizes, inputs used, management of community-based irrigation systems, and benefits and constraints faced in wastewater farming. Four focus-group discussions were also conducted separately with men and women farmers at each site (over the course of one week at Kibera and the following two weeks at Maili Saba). At Maili Saba four men and four women among the respondents from each village were asked to volunteer to attend the focus group discussions, while at Kibera all the respondents were invited to attend. A checklist was used to gather information on gender perspectives in the issues addressed in the household surveys as stated above. The members of the executive committees at the two sites supported the implementation of the survey and helped mobilize farmers to participate.

A feedback workshop was held in April 2008 where findings were discussed with stakeholders and recommendations made on strategies to improve sustainability of community-based wastewater farming.

\section{Data Management and Analysis}

Quality control of the completed questionnaires was carried out every evening by a supervisor who was also the database manager based at Urban Harvest. Urban Harvest ${ }^{1}$ was a systemwide initiative on urban and peri-urban agriculture of the Consultative Groups on International Agricultural Research (CGIAR). Data collected from the survey was entered into the computer using CSPro and analyzed using SPSS (CSPro 3.3; SPSS).

\footnotetext{
1 The Urban Harvest program was closed in 2009. Its website is http://www.uharvest.org/
}

\section{Results and Discussions}

\section{Socioeconomic and Farming Characteristics}

There were an average of four or five persons per household in Kibera and Maili Saba. Forty-two percent of the Kibera households and $28 \%$ of the Maili Saba households were headed by women. The mean age for the female household heads was 47.5 years, and 44.3 for the male household heads (see table 1).

Household heads in Kibera were on average older than those in Maili Saba. The majority of household heads had attained primary education $(54 \%$ in Kibera and 63\% in Maili Saba) (table 1). However, a significantly higher proportion of female household heads $(23 \%)$ had no formal education.

Three-quarters of Maili Saba households owned their houses, compared to half of Kibera households. Since these are informal settlements, this means the households owned the structure but not the land, and as such the households did not have secure land tenure. Sixty percent of children living in the households attended school; the proportion of children attending school did not differ by site or sex of household head.

In both sites the total size of farm per household was small, less than $2,000 \mathrm{~m}^{2}$ ( 0.5 acres). Furrow irrigation, in which water is poured into parallel furrows and flows via gravity, was the most common method of irrigation used; in Kibera it was used by all farmers, while at Maili Saba it was used by $95 \%$ of farmers. The remaining $5 \%$ of farmers at Maili Saba used other irrigation methods, such as flooding, ground seepage, and watering cans. In 
both sites farmers had a schedule for the days of the week and time when each farmer was to irrigate his or her crops. Over $90 \%$ of the farmers grew kale (Brassica oleracea), followed in frequency by maize (Zea mays), which was grown by $86 \%$ of households. The two most popular indigenous vegetables were amaranth (Amaranthus spp.) and African nightshade (Solanum villosum). Other crops grown were spinach (Spinacia oleracea), common beans (Phaseolus vulgaris L), bananas (Musa acuminate), sugarcane (Saccharum officinarum), arrowroot (Maranta arundinaceae $\mathrm{L})$, and sweet potatoes (Ipomoea batatas). Most of the farmers reported that they bought seeds and seedlings, but for amaranth $60 \%$ of the farmers used seed from the previous crop. Seed sourcing was an activity mainly carried out by women.

Self-reported use of pesticides in the wastewaterfarming households was found to be very high at Kibera and Maili Saba, where $78 \%$ and $85 \%$, respectively, of households sprayed their crops. Vegetables were the main crops sprayed. The farmers used various pesticides, most of which researchers found in bottles with missing labels and instructions. This is an indication of the low level of farmers' knowledge of proper use of pesticides. Taking both sites together, use of biological methods was only reported by $17 \%$ of the 195 households that used pesticides. The biological methods of discouraging pests involved use of ash and plant materials such as pepper and tobacco.

Use of manure and/or chemical fertilizer was reported among $47 \%$ of the households and was applied mainly on vegetables. Use of chemical fertilizer was found to be less common among the wastewater-farming households, where it was only applied by $18 \%$ of the surveyed households. The livestock manure was mainly acquired from their own sources, as $67 \%$ of the households that used manure kept livestock. Other sources of livestock manure included receiving it free from friends, neighbors, and relatives, and colleting it free from roadsides. A few farmers bought manure from neighbors.
At Kibera, women and married young men were responsible for watering crops. These young men were hired by women mainly when the women's turn to water was before 6 a.m. or after 6 p.m., due to concerns about security. At Maili Saba, while men were involved in preparing watering channels and furrows, women were most often responsible for opening furrow gates to direct irrigation water to different plots - work that took a lot of time. At Kibera, vegetable harvesting was done by women traders. These traders picked what they wanted from the farm and took it to the owner to be measured and priced. Harvesting at Maili Saba was carried out by women farmers who later took the produce to the markets. In both farms, $60 \%$ of farm labor was provided by women; these results agree with findings of other studies (for example, Hovorka, De Zeeuw, \& Njenga, 2009). It was further found that young adults without families of their own were not involved in wastewater-farming activities. These young people reportedly chose not to be involved in farming because they feared being ridiculed by their peers and were distracted by drinking liquor and idling around shopping centers, while some were employed in various industries in nearby areas. School-aged boys and girls were not involved in farming activities because most were in school during the day and homework took their free time in the evening, while others lacked interest in farm work. As most labor that also took long hours was carried out by women, this implies that women have higher occupational risks emanating from working in wastewater farms. The fact that the younger generation was less involved in this form of farming could pose a sustainability issue for urban agriculture in Kenya.

\section{Contribution of Wastewater Farming to Livelihoods of the Urban Poor}

On average, households in both sites had been involved in wastewater farming for over 10 years, and almost all had no other sources of irrigation water besides wastewater that is tapped from sewer lines. About a third of the farmers interviewed stated that they used wastewater because it was the only source available. 
About 33\% of the respondents mentioned provision of food and ability to generate household income as the most important benefits of wastewater farming (table 2). For instance, over $50 \%$ of the farmers who grew leafy vegetables consumed about a quarter of that produce and sold the rest. In contrast, beans, sweet potatoes, Irish (white) potatoes, and bananas were mainly grown for home consumption.

The survey revealed that wastewater farming provides self-employment to households, where $68 \%$ used labor provided solely by their family members. Provision of employment to others was high at Kibera, where $65 \%$ of the wastewaterfarming households hired workers to assist with farming activities in addition to their own labor.

The other benefits of this type of farming were related to social relationships and psychosocial benefits. The farmers provided food to the neighborhood and provided vegetables at no cost to the less privileged, including an orphanage in the Kibera slums. These farmers believed that they were helping society by ensuring a steady supply of produce at a lower price than what is usually available in the market. They were also bound to one another through the self-help group, which gave them a sense of belonging. They reported that they "looked out for and took care of one another, especially in times of difficulties." Female participants in Kibera also identified several psychosocial benefits of farming, such as feeling healthier since they had something to keep themselves busy rather than being idle, and having to do physical work that they considered good exercise.

Table 2. Benefits Derived From Wastewater Farming According to Interviewed Households

\begin{tabular}{lc}
\hline Benefits & $\begin{array}{c}\text { Percent of } \\
\text { respondents }\end{array}$ \\
\hline $\begin{array}{l}\text { Self-employment where labor was solely } \\
\text { provided by household members }\end{array}$ & 68 \\
$\begin{array}{l}\text { Ability to provide } 75 \% \text { of leafy vegetables } \\
\text { for home consumption }\end{array}$ & 50 \\
Ability to supply food and income & 33 \\
\hline
\end{tabular}

Farmers' Voices on the Benefits of

Wastewater Farming in Nairobi

In order to expand on the benefits of wastewater farming, narratives by representative farmers drawn from Maili Saba and Kibera were captured during the feedback workshop and are shared below with minimal alterations. The real names of the farmers have been concealed for privacy reasons.

Joyce, a farmer from Maili Saba, started rainfed farming in the 1970s on a large tract of land in neighboring Njiru and Ruai. But over the years she and other farmers were pushed and squeezed out by housing estates. They found an opportunity in the wastewater that came from these estates and started using it for irrigated farming in small plots. Initially they used watering cans to irrigate, but after finding it to be very labor-intensive, they started using furrows. They also realized that the wastewater was rich in nutrients, and therefore they did not need to apply fertilizers. Over the years they have used the income they get from wastewater farming to educate their children, even up to college level. At the time of this study, some of the farmers' children were in senior positions where they work. "During the political unrest in early 2008, there was no food coming into the city for several days, and everyone in the neighborhood depended on what we grew," said Joyce. Therefore she felt that wastewater farming contributes a great deal to food security in Nairobi. She requested any information that would improve their farming. James, also from Maili Saba, is one of the pioneer wastewater farmers in Nairobi, and because of that he has participated in numerous lobbying forums and training courses. He represented Nairobi wastewater farmers in the World Water Forum held in Mexico in 2006, and conveyed his gratitude to the International Development Research Center (IDRC) for supporting his trip. His dream is to see urban agriculture on the policy agenda and wastewater farming as one of its components for safe and sustainable urban foods.

Pauline, a farmer from Kibera, started by working as a laborer on the wastewater farms. In 1988 she got a plot of her own on the same farm and began farming. She now has five children and another 
five from her late sister. Though she now has a big family, she is able to feed and educate them using income from the wastewater farm. Pauline stated that there are 36 farmers in the Kibera wastewater farm who live and work as a family despite their different ethnic backgrounds. They share farm implements and inputs such as seeds with each other. Over the years they have acquired a lot of experience in wastewater farming and also learned a lot from their interaction with Urban Harvest and its partners' research.

Margaret has farmed at the Kibera wastewater farm for over 20 years and sells over $80 \%$ of her pro-

\section{Figure 2. Ruth Weeding Vegetables Irrigated Using Wastewater in Nairobi, May 2008}

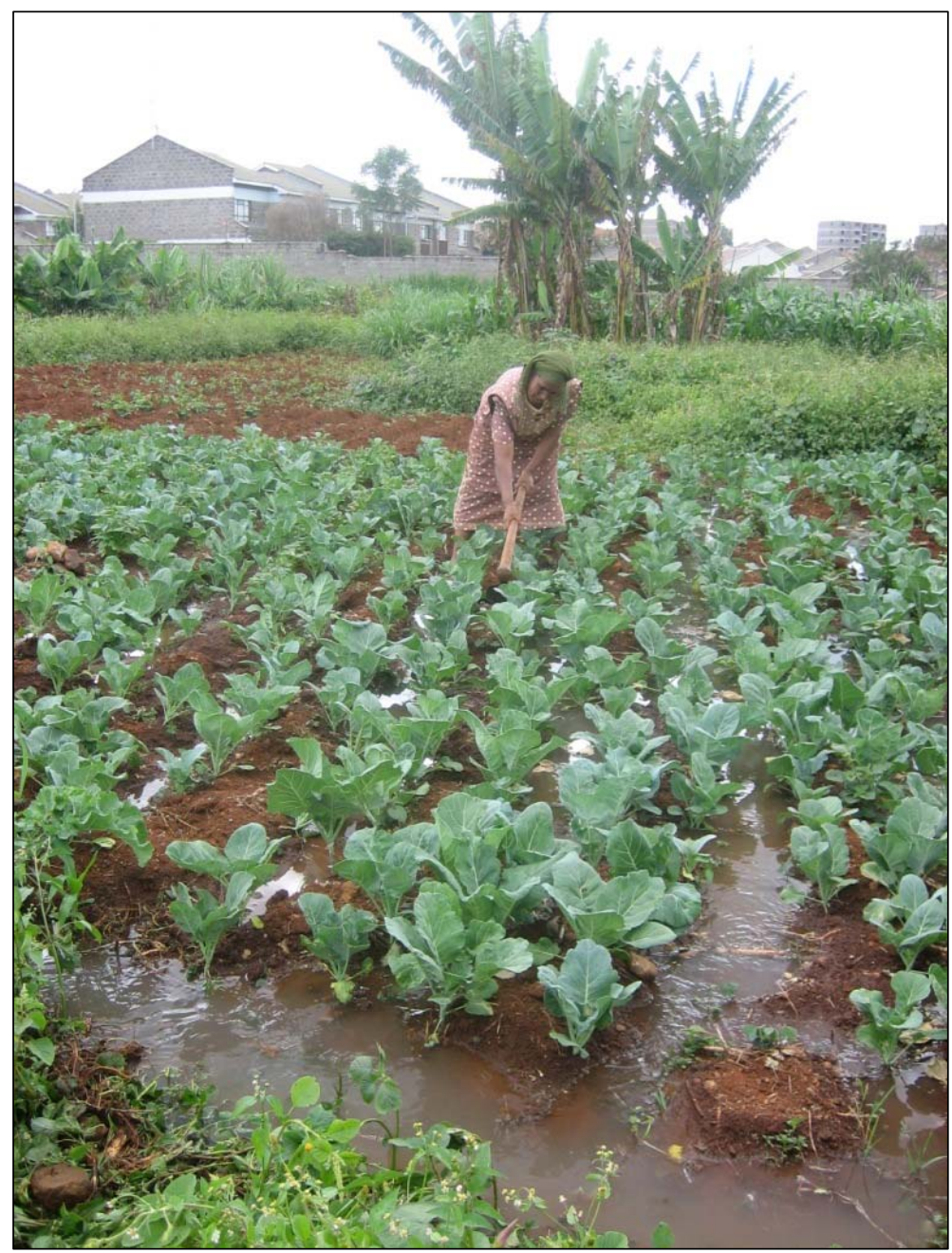

Photo by Mary Njenga. duce. She supported and educated her family using income she got from selling amaranthus, black nightshade, kale, and spinach to Kibera residents. She was able to purchase a piece of land in her rural home area for her family's retirement. She said that she was happy to have created job opportunities for urban youth; she had two fulltime employees on her farm and engages several casual workers during peak planting and weeding periods. Using wastewater enabled her to have produce throughout the year and more so during the dry season, when less produce is received in the city center from rural areas.

Joseph's farming system changed after 2004, when a scientist from Senegal assisting with an urban agriculture course visited the farm accompanied by Urban Harvest. He advised Joseph to start growing high-value crops such as vegetables from which he could get income throughout the year. Since then he has had continuous employment and his income has allowed him to meet his family's needs throughout the year. In fact, he confessed that he had no plans to retire to his rural home in Nyeri, as urban agriculture was providing him with the income he needed.

\section{Farmer's Perceptions and Knowledge About Health Risks Associated With Wastewater Farming}

Twenty-seven percent of the interviewed farmers in Kibera and 56\% in Maili Saba mentioned that using untreated wastewater posed health risks to them. In addition, $34 \%$ of these households reported that at least one member of their families had health problems that may have been caused by wastewater. The gender of those affected was $33 \%$ of male adults, $63 \%$ of female adults, $26 \%$ of youth (13-25 years), and $26 \%$ of children. More female adults were found to be affected, which could be associated with the fact that, as previously described, most 
farming activities were performed by them and hence they were more exposed to the risks. Farmers had devised ways of minimizing biological contamination of the crops, such as applying water through furrow irrigation, which was practiced by all farmers at Kibera and by $95 \%$ of farmers at Maili Saba. Fifty-eight percent and $63 \%$ of respondents in Kibera and in Maili Saba, respectively, used protective clothing while working in the wastewater farms. The most commonly used type of protective clothing was gumboots, used by $54 \%$ of those in Kibera and 50\% of those in Maili Saba who used protective clothing. Other protective clothing used include gloves $(6 \%)$ and dust coats $(3 \%)$. Other mitigation measures adopted by the farmers included growing crops on ridges, washing them before eating, and cooking them properly. There was no mention by the farmers of mitigating the effects of heavy metal contamination, which may imply that they were not aware of such issues.

\section{Challenges Faced by Wastewater Farmers}

During the focus-group discussions and feedback workshop, farmers identified insecure land tenure, conflict with the city council, and competition for land between agriculture and housing and other uses as some of the major threats to their farming. A summary of these challenges is presented below with some unique elements from each site.

\section{Challenges in Maili Saba}

- Private vs. public interest: Most of the land is privately owned by an influential politician who has rented to the farmers at USD8 per year. Farmers had no problem with this informal arrangement, but were suspicious of how the land was acquired by the owner.

- Agriculture vs. housing: Due to rapid population increases (brought about by rural-urban migration) and manipulation of political votes, there was uncontrolled settlement in the wastewater farm areas.

- Agriculture vs. environmental conservation: One of the objectives of forming the self-help group was to protect the environment, which translates into sustainable utilization of resources. While the older generation embraced communal protection of the farmland, the younger generation was more interested in getting quick money from quarrying (for building stones) with little consideration for tomorrow's environmental effects.

- Agriculture vs. politics: Politicians won youth votes by promising free allotments of the same land farmers had been using for over 30 years. The central government had agriculture extension staff visiting farmers while the city council and the Nairobi Water and Sewage Company were enforcing regulations against the use of wastewater. This confused the farmers as to the longterm policy support for their wastewaterfarming activities.

\section{Challenges in Kibera}

- Private vs. public interest. Farming took place on land owned by a parastatal institution that had an informal agreement with farmers, but the continuation of their tenure was unsure despite the fact that the farmers had been farming there for the last 20 years.

- Ethnocultural and social groupings: Farmers were still linked to their original socioeconomic groups. These were very diverse in terms of activities and cultural backgrounds, where for example some preferred to grow certain traditional vegetables based on the types they grew in their original rural homes, which in turn affected the group's farming approaches.

- Agriculture vs. development: The farming area was being encroached on by construction of bypass roads to ease congestion in the city center and by construction of high-rise buildings.

- Male vs. female access to irrigation water: There was insufficient wastewater, and men had the advantage of being able to water at night when it was too risky for women to do the same.

- Agriculture vs. law enforcement: Farmers were unwilling to abide by regulations that stipulated that the height of crops should be below one 
meter (3.28 feet). This was because they are accustomed to selling maize, sugarcane, and fodder crops. The blocking of sewer lines by farmers to source wastewater also resulted in conflicts with local government lawenforcement officers.

\section{Sharing of Findings with Stakeholders}

A feedback workshop on the "benefits and risks in wastewater irrigation in urban and peri-urban agriculture" project was held on 28 April 2008 in Nairobi, where findings of the project were discussed among stakeholders. These included farmers and staff from national and international research and training institutions, nongovernmental organizations, government departments from both central and local governments, and development partners. Following presentations of the research findings, participants worked in groups to propose recommendations on research and development for the sustainable use of wastewater for poverty alleviation and food security. These recommendations and those of the research team are presented in the following section. Farmers elaborated on benefits accrued and challenges that they faced in this type of farming (presented above).

\section{Conclusions and Policy Implications}

Wastewater farming contributes to improved livelihoods for the urban poor. The food supplied from wastewater farms, for example, not only benefits the farmers, but also their neighbors in these informal settlements. Families in the informal settlements can buy food at lower prices than what is offered in markets. Some of the less privileged members of these societies receive food from the farmers at no cost. Farmers generate income they use to meet their household needs as well as to acquire assets such as land in rural areas. This type of farming creates employment and strengthens social networks through which the urban poor take care of each other in times of need. It was also noted that wastewater farming contributed to psychosocial health, particularly among women. Fewer than half the farmers were using either manure or fertilizer, citing the presence of plant nutrients in the wastewater, which helped them to save on the costs of inputs.
The high rate of pesticide application, coupled with a low level of knowledge about pesticide safety, calls for (1) research on the impacts on human beings and the environment, and also (2) technical capacity-building on the safe use of pesticides. Women were faced with security issues whenever their turn to access the irrigation water was at dawn or late in the evening, and as such they needed to spend part of their income hiring young men to water their crops. This indicates a need to consider gender issues when designing irrigation systems in urban areas. The farmers also faced the challenges of insecure land tenure and experienced various forms of conflict over resource use that threatens sustainability of their livelihoods from wastewater farming. There is a need to establish platforms and networks to form avenues for conflict resolution in wastewater farming, as well as holding dialogues on issues affecting farmers with government departments such as Nairobi City Council and the ministries of agriculture and livestock. This includes involvement of stakeholders in the ongoing process of developing a national policy that incorporates urban agriculture into urban land-use planning. While farmers were often aware of the health risks emanating from biological contaminants, they had absolutely no knowledge about the presence of heavy metals and possible risks that these might bring. There is a need for testing, dissemination, and communication of appropriate, cost-effective, and sustainable technologies such as irrigation methods, stabilization ponds that minimize risks, and growing of high-value crops and plants (such as forestry products, ornamentals, and seed).

Public and environmental risks associated with wastewater farming have been studied in the same sites and findings shared in various stakeholder forums as well as through publications such as Karanja, et al. (2010).

The time has come, however, when any form of urban agriculture demands government recognition so that the necessary institutional frameworks can be put in place to integrate these activities into existing urban planning. 


\section{Acknowledgements}

The authors would like to express their gratitude to International Development Research Centre (IDRC) for its financial support, without which this study would not have been undertaken. We highly appreciate the participation of the Kenya Water Institute, Jomo Kenyatta University of Agriculture and Technology, and the University of Nairobi in this project, and all other stakeholders who joined in the feedback session. Many thanks go to all the farmers who participated in this study, and we highly appreciate the assistance offered to the research team by the group leaders at Kibera and Maili Saba farms.

\section{References}

Armar-Klemesu, M. (2000). Urban agriculture and food security, nutrition and health. In N. Bakker, M. Dubbeling, S. Gundel, U. Sabel-Koschella, \& H. de Zeeuw (Eds.). Growing cities, growing food. Urban agriculture on the policy agenda (pp. 99-117). Feldafing, Germany: Zentralstelle für Ernahrung und Landwirtschaft (ZEL), Food and Agriculture Development Centre.

Carr, R. M., Blumenthal, U. J., \& Mara, D. D. (2004). Health guidelines for the use of wastewater in agriculture: Developing realistic guidelines. In C. A. Scott, N. I. Faruqui, \& L. Raschid-Sally (Eds.), $W$ astewater use in irrigated agriculture: Confronting the livelibood and environmental realities (pp. 41-58). CAB International in Association with International Water Management Institute and the International Research Development Centre. doi:10.1079/9780851998237.0041

CSPro 3.3 [Computer software]. Washington, DC: International Programme Centre, U.S. Census Bureau.

Denninger, M., Egero, B., \& Lee-Smith, D. (1998). Urban food production: A survival strategy of urban households (RELMA Workshop Series I). Nairobi: Regional Land Management Unit (RELMA), Mazingira Institute.

Faruqui, N. I., Niang, S., \& Redwood, M. (2004). Untreated wastewater use in market gardens: A case study of Dakar, Senegal. In C. A. Scott, N. I. Faruqui, \& L. Raschild-Sally (Eds.), W astewater use in irrigated agriculture: Confronting the livelihood and environmental realities. Oxfordshire, UK: CAB International. doi:10.1079/9780851998237.0113

Foeken, D., \& Mwangi, A. M. (2000). Increasing food security through urban farming in Nairobi. In N. Bakker, M. Dubbeling, S. Gundel, U. Sabel-
Koschella, \& H. Zeeuw (Eds.), Growing cities, growing food: Urban agriculture on the policy agenda (pp. 303328). Feldafing, Germany: Zentralstelle für Ernahrung und Landwirtschaft (ZEL), Food and Agriculture Development Centre.

Gyiele, L. (2002). Integrated economic and environmental impact assessment of urban and peri-urban agriculture in and around Kumasi. Vol. 1 and 2 of the Final Report submitted to FAO (Project PR 17951). Kumasi, Ghana, IWMI-IBSRAM and KNUST.

Haluna, S. (2002). The contribution of urban agriculture to household food security in the Tamala Municipality (unpublished project report).

Hide, J. M., Kimani, J., \& Kimani Thuo, K. (2001). Informal irrigation in the peri-urban zone of Nairobi: $A n$ analysis of farmer activity and productivity (Report OD/TN 104). HR Wallingford Ltd.

Hinrichsen, D., Robey, B., \& Upadhyay, U. D. (1998). Solutions for a water-short world. (School of Public Health Population Reports, Series M, No. 4). Baltimore, Maryland: John Hopkins University.

Hovorka, A., de Zeeuw, H., \& Njenga, M. (Eds.). (2009). Women feeding cities: Mainstreaming gender in urban agriculture and food security. Rugby, UK: Practical Action Publishing.

Jimenez, B., \& Asano, T. (2004, December). Acknowledge all approaches: The global outlook on reuse. Water, 21, 32-37.

Karanja, N., Njenga, M., Prain, G., Kang'ethe, E., Kironchi, G., Githuku, C., Kinyari, P., \& Mutua, G. K. (2010). Assessment of environmental and public health hazards in wastewater use for urban agriculture in Nairobi, Kenya. Journal of Tropical and Subtropical Agroecosystems, 12, 85-97.

Kenya, Government of (GOK). (2010). 2009 Kenya Population and Housing Census: Volume II, Population and Household Distribution by Socio-Economic Characteristics. Nairobi: Government Printers.

Maxwell, D. (1995). Labour, land, food and farming: A bousehold analysis of urban agriculture in Kampala, Uganda (Unpublished doctoral dissertation). Madison, Wisconsin: University of Wisconsin-Madison.

Metcalf and Eddy, Inc. (2003). W astewater engineering: Treatment, disposal and reuse (4th edition). New York: McGraw-Hill.

Ministry of Planning and National Development, Kenya (MoPND). (2003). Economic Survey.

Mougeot, L. J. A. (1994). African city farming from a world perspective. In A. G. Egziabher, D. LeeSmith, D. G. Maxwell, P. A. Memon, L. J. A. Mougeot, \& C. J. Sawio (Eds.), Cities feeding people: An examination of urban agriculture in East Africa (pp. 1-24). Ottawa, Canada: International Development Research Centre (IDRC). 
Nabulo, G., Oryem-Origa, H., \& Diamond, M. (2006). Assessment of lead, cadmium, and zinc contamination of roadside soils, surface films, and vegetables in Kampala City, Uganda. Environmental Research, 101, 42-52. doi:10.1016/i.envres.2005.12.016

Prain, G., Karanja, N., \& Lee-Smith, D. (Eds.). (2010). African urban harvest: Agriculture in the cities of Cameroon, Kenya and Uganda. Co-published by International Development Research Centre (IDRC) and the International Potato Center (CIP). London: Springer.

Scott C. A.., Faruqui, N. I., \& Rashid-Sally, L. (2004). Wastewater use in irrigated agriculture: Management challenges in developing countries. In C. A. Scott, N. I. Faruqui, \& L. Raschid-Sally (Eds.), $W$ astewater use in irrigated agriculture: Confronting the livelihood and environmental realities (pp. 1-10). CAB International in Association with International Water Management Institute and the International Research Development Centre.

Smit, J., \& Nasr, J. (1992). Urban agriculture for sustainable cities: Using wastes, idle land and water bodies as resources. Environment and Urbanization, 4(2), 141-142. doi:10.1177/095624789200400214

Smit, J., Ratta, A., \& Nasr, J. (1996). Urban agriculture: Food, jobs and sustainable cities (Publications Series for Habitat II, Vol. I). New York: United Nations Development Programme (UNDP).

SPSS (Version 15.0) [Computer software]. PASW Statistics.

United Nations Human Settlements Programme (UNHabitat). (2006). State of the world's cities 2006/7. Sterling, Virginia: Earthscan.

United Nations (UN) (2008, July). Comprehensive framework for action. High-Level Task Force on the Global Food Security Crisis. New York: Self. Accessible from http://www.un.org/ issues/food/taskforce/Documentation/ CFA\%20Web.pdf

United Nations Population Fund (UNFPA). (2007). State of the world population, unleashing the potential of urban growth. New York: Self. 